\title{
Serine/Threonine-Protein Kinase 4
}

National Cancer Institute

\section{Source}

National Cancer Institute. Serine/Threonine-Protein Kinase 4. NCI Thesaurus. Code C99483.

Serine/threonine-protein kinase 4 (487 aa, $\sim 56 \mathrm{kDa}$ ) is encoded by the human ST K4 gene. This protein is involved in the mediation of serine/threonine phosphorylation and hippo signaling. 